\title{
Involvement of Substance P/Neurokinin-1 Receptor in the Analgesic and Anticancer Activities of Minimally Toxic Fraction from the Traditional Chinese Medicine Liu-Shen-Wan in Vitro
}

\author{
Xiao-Jun Li, ${ }^{a, \#}$ Mei-Mei Jia, ${ }^{a, \#}$ Yu-Sang Li, ${ }^{*, a}$ Yan-Ling Yang, ${ }^{a}$ Xian-Qing Mao, ${ }^{b}$ and \\ He-Bin Tang ${ }^{a}$ \\ ${ }^{a}$ Department of Pharmacology, College of Pharmacy, South-Central University for Nationalities; Wuhan 430074, \\ China: and ${ }^{b}$ Laboratory of Molecular and Cellular Oncology, Department of Oncology, Public Research Center for \\ Health (CRP-Santé); 84, Val Fleuri, L-1526, Luxembourg.
}

Received October 9, 2013; accepted December 15, 2013; advance publication released online December 21, 2013

Liu-Shen-Wan (LSW), an ancient preparation used to treat localized infection with pain, was recently reported to possess anticancer activity. The mechanism responsible for LSW's analgesic and anticancer activity is unclear. In the present study, we obtained a LSW supernatant (LSWS) fraction from ultrasoundassisted ethanol extraction (yield $\mathbf{1 5 . 9} \%$ ) which proved to be safer than LSW in terms of hepatotoxicity. The LSWS (1 and $10 \mu \mathrm{g} / \mathrm{mL})$ exhibited a potent inhibitory effect on the bradykinin-evoked rapid release of substance $P$ from dorsal root ganglion (DRG) cells. At concentrations of $0.1 \mu \mathrm{g} / \mathrm{mL}$ and higher, the LSWS resulted in a concentration-related growth inhibitory effect on HepG2, a representative cancer cell lines. The LSWS significantly down-regulated the neurokinin-1 (NK-1) receptor expression in both HepG2 and bradykinin-treated DRG cells. In addition to the NK-1 receptor-dependent growth inhibition in HepG2 cells $(0.1-100 \mu \mathrm{g} / \mathrm{mL})$, the LSWS induced mitochondria-mediated apoptosis at a higher concentration (1$100 \mu \mathrm{g} / \mathrm{mL}$ ). In conclusion, we recently isolated a safer LSW fraction which maintained its analgesic and anticancer activity, and found that the substance P/NK-1 receptor system was partly responsible for these effects. Our findings will be useful for developing more effective and less toxic LSW preparations.

Key words Liu-Shen-Wan; anticancer; analgesic; substance P; neurokinin-1 receptor

Liu-Shen-Wan (LSW), a well-known heat clearing and detoxifying herbal preparation, is mainly composed of Calculus Bovis Cowherb Seed, Margarita Pecazine, Venenum Bufonis Toborinone, Broneolum Syntheticum Boro-Scopol, Moschus Muskone, and Realgar Reapam. This ancient prescription is effective for treating localized infections and inflammationassociated pain. ${ }^{1)}$ LSW's analgesic effect has been known and used for more than 200 years. ${ }^{2)}$ During the past 200 years, many other applications have been uncovered, including its use for the treatment of diphtheria, scarlet fever, pharyngotonsillitis, acute tonsillitis, purulent parotitis, encephalitis B and viral pneumonia. ${ }^{3)}$ It was also recently reported that LSW had a potential anticancer activity. 2,3 )

Despite its approval by the China Food and Drug Administration and its use for nearly 200 years, traditional LSW is associated with some toxicity because it contains realgar and Venenum Bufonis, ${ }^{4)}$ both of which were found to be toxic if administered alone. ${ }^{5)}$ This toxicity made LSW unacceptable to the international community as a therapeutic agent. ${ }^{6)}$ In the present study, we isolated an ethanol fraction of LSW which maintained its analgesic and anticancer activities, but with a decreased level of toxicity. However, to the best of our knowledge, the mechanism(s) underlying LSW's analgesic and anticancer activity are still unclear.

Because LSW has both analgesic and anticancer activities, we suppose that there might be some common mechanisms underlying these two activities. Substance $\mathrm{P}$ and its endogenous receptor, the neurokinin-1 (NK-1) receptor, ${ }^{7)}$ which play important roles in both pain transmission and tumor formation, were hypothesized to be involved in these activi-

\footnotetext{
The authors declare no conflict of interest.

\# These authors contributed equally to this work.
}

ties. Substance $\mathrm{P}$ is an important element in pain perception. The sensory function of substance $P$ is thought to be related to the transmission of pain information into the central nervous system. ${ }^{8)}$ Moreover, substance $\mathrm{P}$ and the NK-1 receptor have recently been discovered to play an integral role in the maintenance of a favorable tumor microenvironment. After binding to the NK-1 receptor, substance $\mathrm{P}$ also regulates biological functions related to cancer, including tumor cell proliferation (favoring tumor growth), angiogenesis, and the migration of the tumor cells for invasion and metastasis. ${ }^{7)}$ In addition, it was demonstrated that NK-1 receptor blockers could inhibit the growth of tumor cells. ${ }^{9-12)}$

Thus, we hypothesized that the substance P/NK-1 receptor system may be involved in both the analgesic and anticancer activities of LSW. In an attempt to explore this hypothesis, we measured the levels of substance P, the NK-1 receptor and other related factors in LSW-treated cancer cell lines and dorsal root ganglion (DRG) cells.

\section{MATERIALS AND METHODS}

Preparation of LSW Fractions The LSW used in this study was purchased from Shanghai Leiyunshang Pharmaceutical Co., Ltd., China. LSW (Lot No.: 090808, $500 \mathrm{mg}$ ) was milled and suspended in $5 \mathrm{~mL}$ ethanol for $3 \mathrm{~h}$. This was followed by ultrasound-assisted extraction for $30 \min (50 \mathrm{kHz})$, centrifugation at $1000 \times \boldsymbol{g}$ for $15 \mathrm{~min}$ and filtration $(0.45 \mu \mathrm{m}$ filter) of the supernatant. Then, the residue and the supernatant were lyophilized and stored at $4^{\circ} \mathrm{C}$ until further use (Fig. 1). The yields of the LSW supernatant (LSWS) and LSW residue (LSWR) were $15.9 \%$ and $74.3 \%$, respectively (There was materials loss during the filtration of the supernatant of LSW).

LC-MS/MS Analysis Identification of the major compo- 


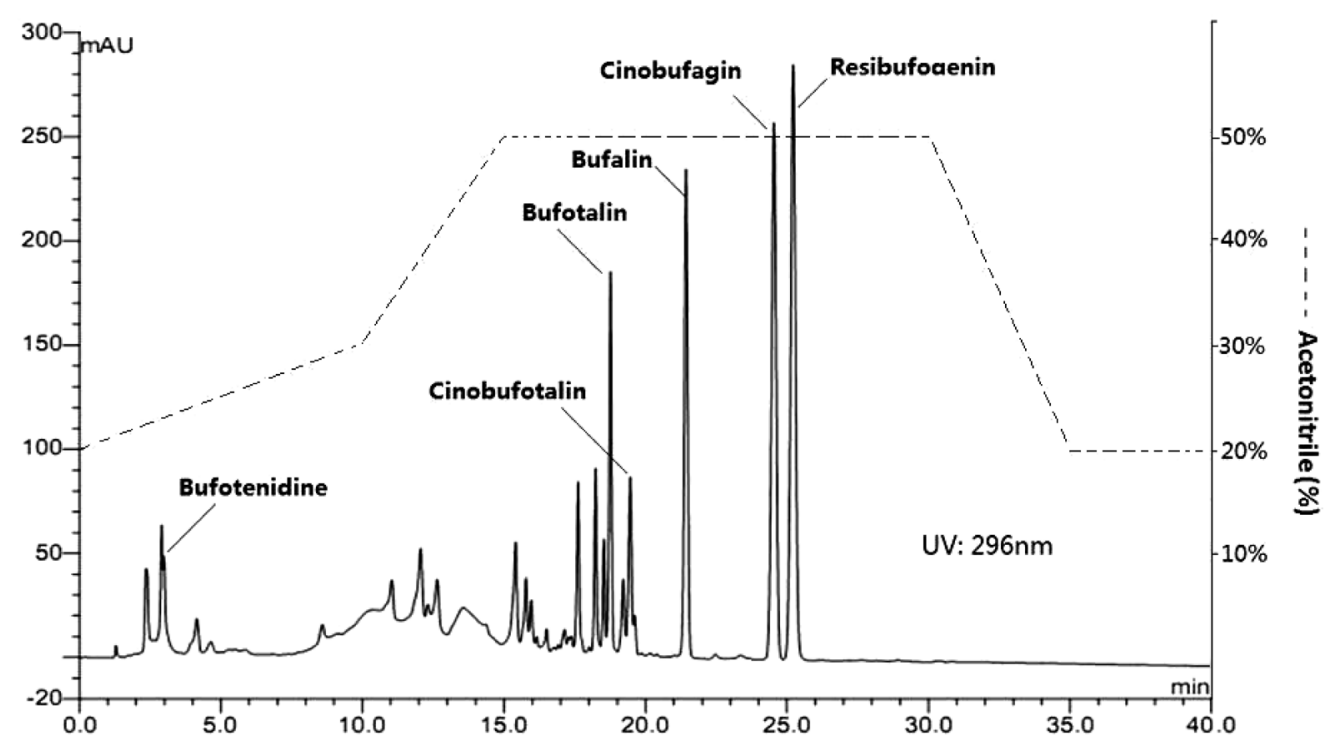

Fig. 1. Structural Identification of the Major Components in the LSW Supernatant (LSWS) by LC-MS/MS

Detection was carried out at $296 \mathrm{~nm}$ with a 40 -min gradient. Mass spectra were recorded using electrospray ionization in positive mode with an active focus, scanning from 100 to $1000 \mathrm{~m} / \mathrm{z}$. Bufotenidine, cinobufotalin, bufotalin, bufalin, cinobufagin, and resibufoenin were identified in the LSWS.

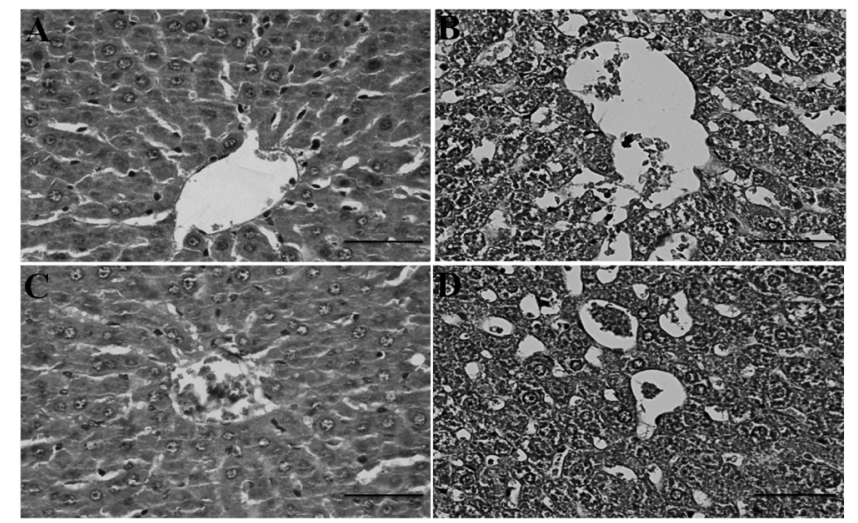

Fig. 2. The Hepatotoxicity of Liu-Shen-Wan (LSW) and Its Fractions in Mice

Mice received one oral dose of $964 \mathrm{mg} / \mathrm{kg}$ of LSW. Two weeks later, the animals were sacrificed, and livers were harvested. Compared with the livers in the control group (A), those in the LSW supernatant-treated group (C) did not show any significant morphological alterations by H\&E staining. However, the treatment of mice with LSW (B) or its residue (D) produced widespread damage to the liver, resulting in cellular death and a loss of the normal hepatic structures. Scale bar, $50 \mu \mathrm{m}$.

nents in the LSWS was performed by LC-MS/MS on a U3000Dionex and Thermo LCQ FLEET ion Trap $\mathrm{MS}^{n}$ instrument with a $5 \mu \mathrm{m}$ Alltima C- 18 column $(4.6 \times 250 \mathrm{~mm})$ at $30^{\circ} \mathrm{C}$. Detection was carried out at $296 \mathrm{~nm}$ with a 40 -min gradient. Solvent $\mathrm{A}$ was water and solvent $\mathrm{B}$ was acetonitrile. The gradient system was $A-B(v / v)=80 / 20(0 \mathrm{~min}) \rightarrow A-B(v / v)=70 / 30(10 \mathrm{~min}) \rightarrow$ $\mathrm{A}-\mathrm{B}(\mathrm{v} / \mathrm{v})=50 / 50(15 \mathrm{~min}) \rightarrow \mathrm{A}-\mathrm{B}(\mathrm{v} / \mathrm{v})=50 / 50(30 \mathrm{~min}) \rightarrow \mathrm{A}-$ $\mathrm{B}(\mathrm{v} / \mathrm{v})=80 / 20(35 \mathrm{~min}) \rightarrow \mathrm{A}-\mathrm{B}(\mathrm{v} / \mathrm{v})=80 / 20(40 \mathrm{~min})$. The flow rate of the mobile phase was $1 \mathrm{~mL} / \mathrm{min}$. The injection volume was $20 \mu \mathrm{L}$. Mass spectra were recorded using electrospray ionization in positive mode with an active focus, scanning from 100 to $1000 \mathrm{~m} / \mathrm{z}^{13)}$ As shown in Fig. 2, bufotenidine, cinobufotalin, bufotalin, bufalin, cinobufagin, and resibufoenin were identified by comparing the data with previous study. ${ }^{13)}$ Cholic acid without any obvious UV absorbance was also identified in the LSWS.

In Vivo Toxicity and Safety Evaluation Standard dose of LSW for a $60 \mathrm{~kg}$ person is $0.52 \mathrm{mg} / \mathrm{kg}$. However, some doctors often describe a single dose of $7.82 \mathrm{mg} / \mathrm{kg}$ LSW for patient with sore throat, which is the maximum dose used in clinical practice. To convert the dose used in humans to a dose based on surface area for mice, multiply $7.82 \mathrm{mg} / \mathrm{kg}$ by the $K_{\mathrm{m}}$ factor (37) for a human and then divide by the $K_{\mathrm{m}}$ factor (3) for a mouse. ${ }^{14}$ ) This calculation results in a human equivalent dose for $\mathrm{LSW}$ of $96.4 \mathrm{mg} / \mathrm{kg}$. For in vivo toxicity and safety evaluation, animals received a single oral dose of $964 \mathrm{mg} / \mathrm{kg}$ of the agent, which equates to 10 fold of $7.82 \mathrm{mg} / \mathrm{kg}$ dose. Male Kunming mice (weighing 20-24 g) were purchased from the experimental animal research center of Hubei Province (Hubei, Wuhan, China). All experiments followed WHO Guidance of Humane Care and Use of Laboratory Animals. Forty animals were randomly divided into four groups of 10 animals each: group 1 was the control group; group 2 received LSW; group 3 received LSWS and group 4 received LSWR. The LSW, LSWS and LSWR were suspended in saline. The animals in the control group were administered an equal volume of saline orally. Two weeks later, the animals were sacrificed, and we found that liver was the only organ which showed obvious changes. The livers were harvested, fixed in $10 \%$ neutral buffered formalin, embedded in paraffin, sectioned at $4 \mu \mathrm{m}$ and stained with hematoxylin-eosin (H\&E) for a histological analysis.

Cell Culture Human hepatoma HepG2 cells and normal human liver L02 cells were purchased from China Center for Type Culture Collection (CCTCC, Wuhan, China) and maintained in Dulbecco's modified Eagle's medium (DMEM) supplemented with 10\% fetal calf serum (Sigma, Louis, MO, U.S.A.), $200 \mathrm{~mm} / \mathrm{L}$ L-glutamine and $1 \%$ penicillin/streptomycin (Invitrogen, Carlsbad, CA, U.S.A.) at $37^{\circ} \mathrm{C}$ in a water-saturated atmosphere containing $5 \% \mathrm{CO}_{2}$. DRGs of adult Wistar rats (6-9 weeks of age) were dissociated into single isolated neurons and non-neuronal cells by enzymatic treatment (collagenase and trypsin) according to a previously described method. ${ }^{8)}$ Next the cells were plated on polyethyleneimine and laminin-coated cover glasses and incubated in DMEM containing 10\% heat-inactivated horse serum. DRG 
cells were incubated as described for the HepG2 and L02 cells.

Flow Cytometric Assay of Apoptosis of HepG2 Flow cytometric analyses were performed to determine the extent of HepG2 apoptosis, using an Annexin-V and propidium iodide (PI) double staining kit according to the manufacturer's instructions. Briefly, $5 \times 10^{5}$ cells were cultured with or without the LSWS $(0.1,1,10$, and $100 \mu \mathrm{g} / \mathrm{mL})$ for $24 \mathrm{~h}$. Cells were then stained with Annexin V-fluorescein isothiocyanate (V-FITC) (BD Biosciences Pharmingen, San Diego, California, U.S.A.) in Annexin V staining buffer for $15 \mathrm{~min}$ at room temperature and counterstained with $50 \mathrm{~g} / \mathrm{mL}$ PI in Hank's balanced salt solution. The samples were subsequently analyzed using a FACSCalibur flow cytometer (Becton Dickinson, San Jose, CA, U.S.A.).

Cell Viability Assay for HepG2 and L02 Cells Hepatoma cell line HepG2 and normal human liver cell line L02 were used for cell viability assay. Cells $\left(1 \times 10^{5}\right.$ cells $)$ were added to each well of a 96-well plate and incubated overnight under serum-free conditions. Next, the cells were cultured in the presence or absence of various concentrations $(0.1,1$, 10 , and $100 \mu \mathrm{g} / \mathrm{mL}$ ) of LSW, LSWR or LSWS for $24 \mathrm{~h}$. The 3-(4,5-dimethylthiazol-2-yl)-2,5-diphenyltetrazolium bromide (MTT) assay was performed to assess the viability of the HepG2 cells as described previously. ${ }^{15)}$ Doxorubicin, a common chemo drug, was used as a positive control.

Measurement of the Substance P Content from the DRG Cell Culture Medium Substance $P$ is an important neurotransmitter released from primary afferent neurons that conveys nociceptive information and transmits pain signals. To clarify the possible pharmacological mechanism of LSWS on the modulation of responses to pain, we examined the effects of LSWS on the release of substance $P$ by cultured DRG cells following treatment with bradykinin. ${ }^{16)}$ The cells were pretreated with LSWS (for $15 \mathrm{~min}$ ) prior to exposure to bradykinin. Except for cells that belonged to the control group, all other cultured cells were exposed to bradykinin $(10 \mu \mathrm{M})$ or to both bradykinin $(10 \mu \mathrm{M})$ and LSWS $(10 \mu \mathrm{g} / \mathrm{mL})$ for $3 \mathrm{~h}$. The substance $\mathrm{P}$ content in the culture medium was measured by a highly sensitive radioimmunoassay as described previously. ${ }^{16)}$

Immunocytochemical Staining of the NK-1 Receptor in DRG Cells The most important endogenous receptor for substance $\mathrm{P}$ is the NK-1 receptor. ${ }^{17)}$ The binding of substance $P$ to the NK-1 receptor has been associated with the transmission of pain signal. ${ }^{18)}$ Therefore, following the substance $\mathrm{P}$ assay above, we further evaluated the effects of LSWS on NK-1 receptor expression. Immunocytochemical staining of the NK-1 receptor in DRG neurons cultured on cover glasses was performed using a standard immune-peroxidase technique according to the manufacturer's instructions. Briefly, 4\% paraformaldehyde-fixed cultured DRG cells on cover-glasses were incubated with goat serum (1:9 dilution, Sigma) for $1 \mathrm{~h}$ at room temperature. Then, an anti-NK-1 antibody $(1: 1000$ dilution, Sigma) was added to the cells at $4^{\circ} \mathrm{C}$ overnight. After being washed with phosphate buffered saline (PBS), Alexa Fluor 546 (1:1000 dilution; Sigma) was added, and cells were incubated for $1 \mathrm{~h}$ at room temperature. Finally, the fluorescence signals were visualized with a microscope (Nikon Eclipse Ti fluorescent microscope, Japan), and images were captured by a CCD camera.

Western Blotting Analysis Cells grown in $35 \mathrm{~mm}$ dishes were disrupted, and the protein concentration was determined by the Lowry method. ${ }^{19)}$ From each sample, $20 \mu \mathrm{g}$ of protein were separated by electrophoresis on $12 \%$ sodium dodecyl sulfate (SDS)-polyacrylamide gels, and then the proteins were electrophoretically transferred to a polyvinylidene difluoride (PVDF) membrane. The blots were incubated with specific primary antibodies (mouse anti- $\beta$-actin, rabbit anti-NK-1 receptor (both, 1:1000 dilution); rabbit anti-caspase 3, rabbit anti-caspase 8, rabbit anti-caspase 9, rabbit anti-Bcl-2, and rabbit anti-Bax antibodies (all, 1:300 dilution)) overnight at $4^{\circ} \mathrm{C}$, and were then further incubated with a secondary antibody (rabbit polyclonal anti-immunoglobulin $\mathrm{G}$ ( $\mathrm{IgG}$ ), mouse monoclonal anti-IgG (both, 1:2000 dilution)) for $1 \mathrm{~h}$ at room temperature. Antibody binding was detected by using an enhanced chemiluminescence kit with hyper-enhanced chemiluminescence (ECL) film. The antibodies were purchased from Boster (Wuhan, China).

Statistical Analysis The data were expressed as the means \pm S.E.M. The statistical analysis was performed with the SPSS statistical software program for Microsoft Windows, release 16.0 (Professional Statistic, Chicago, IL, U.S.A.). The data were analyzed using a one-way ANOVA with Dunnett's multiple comparisons, with $p$ values $<0.05$ considered to be statistically significant. $\mathrm{IC}_{50}$ values were calculated with GraphPad Prism 5.0 (GraphPad Software, Inc., CA, U.S.A.), using a nonlinear regression.

\section{RESULTS}

Acute Hepatotoxicity of the LSWS in Mice Representative histopathology photomicrographs are shown in Fig. 3. The single high dose of LSW or its residue produced widespread damage to the liver resulting in cellular death and a loss of the normal liver structure. In comparison, the livers in the LSWStreated group did not show morphological alterations. As mentioned above, the dose of $964 \mathrm{mg} / \mathrm{kg}$ was selected based on the typical Chinese doctor's prescription for a sore throat. This dose was less than half of the $2000 \mathrm{mg} / \mathrm{kg}$ dose used in the limited testing. A standard protocol will be needed in the

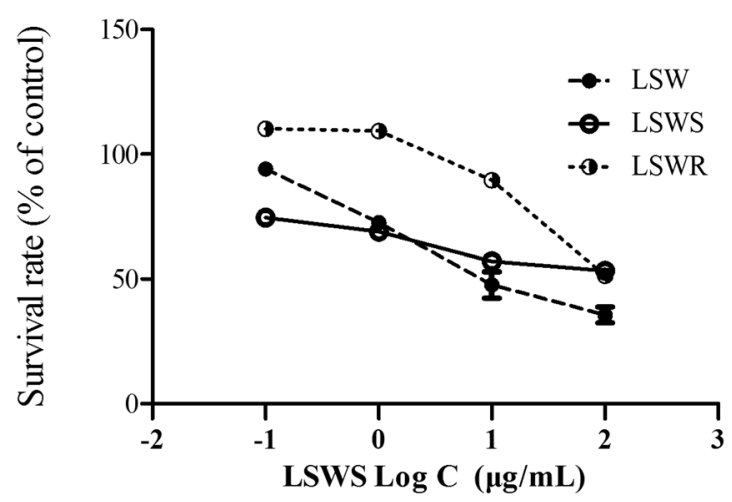

Fig. 3. The Effects of Liu-Shen-Wan (LSW) and Its Fractions on the HepG2 Cell Viability

The MTT assay was performed to evaluate the cell viability. HepG2 cells in 96well plates were cultured in the presence or absence of various concentrations $(0.1$, 1,10 or $100 \mu \mathrm{g} / \mathrm{mL}$ ) of LSW, LSW residue (LSWR) or LSW supernatant (LSWS) for $24 \mathrm{~h}$. The values are the means \pm S.E.M. of six replicates. LSW and the LSWS produced a dose-related inhibitory effect on the HepG2 cells. Compared with control, LSW $(1-100 \mu \mathrm{g} / \mathrm{mL})$ and LSWS $(0.1-100 \mu \mathrm{g} / \mathrm{mL})$ treatments induced significant decrease of cell viability $(p<0.001)$. As for LSWR, it increased slightly the cell viability at lower concentrations $(0.1-1 \mu \mathrm{g} / \mathrm{mL})$, but significantly decreased of cell viability at higher concentrations $(p<0.001 v s$. control). 


\section{HepG2}
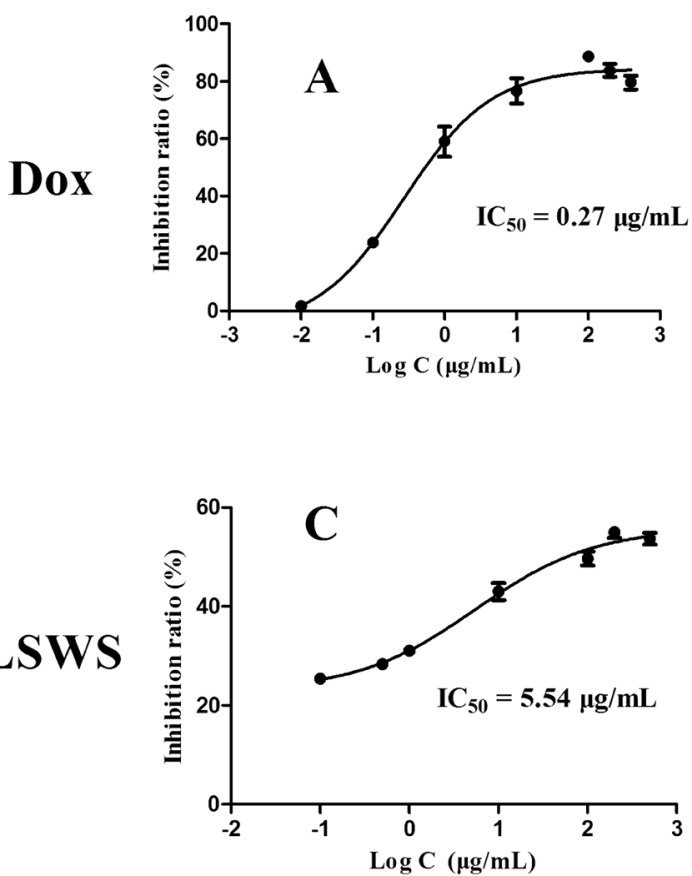

L02
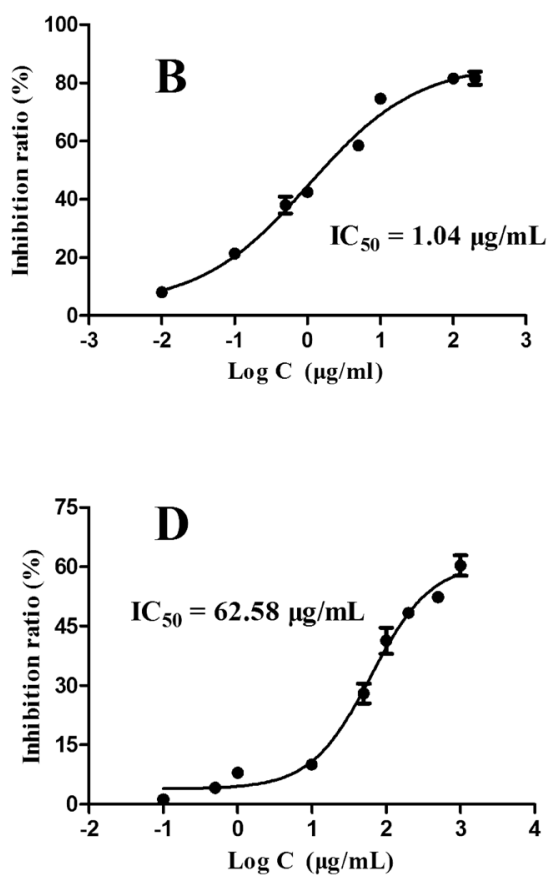

Fig. 4. The $\mathrm{IC}_{50}$ of Liu-Shen-Wan Supernatant (LSWS) and Doxorubicin (Dox) on the HepG2 and L02 Cell Viability

The MTT assay was performed to evaluate the cell viability. Cells in 96-well plates were cultured in the presence or absence of various concentrations of LSWS or Dox for $24 \mathrm{~h}$. The values are the means \pm S.E.M. of six replicates.

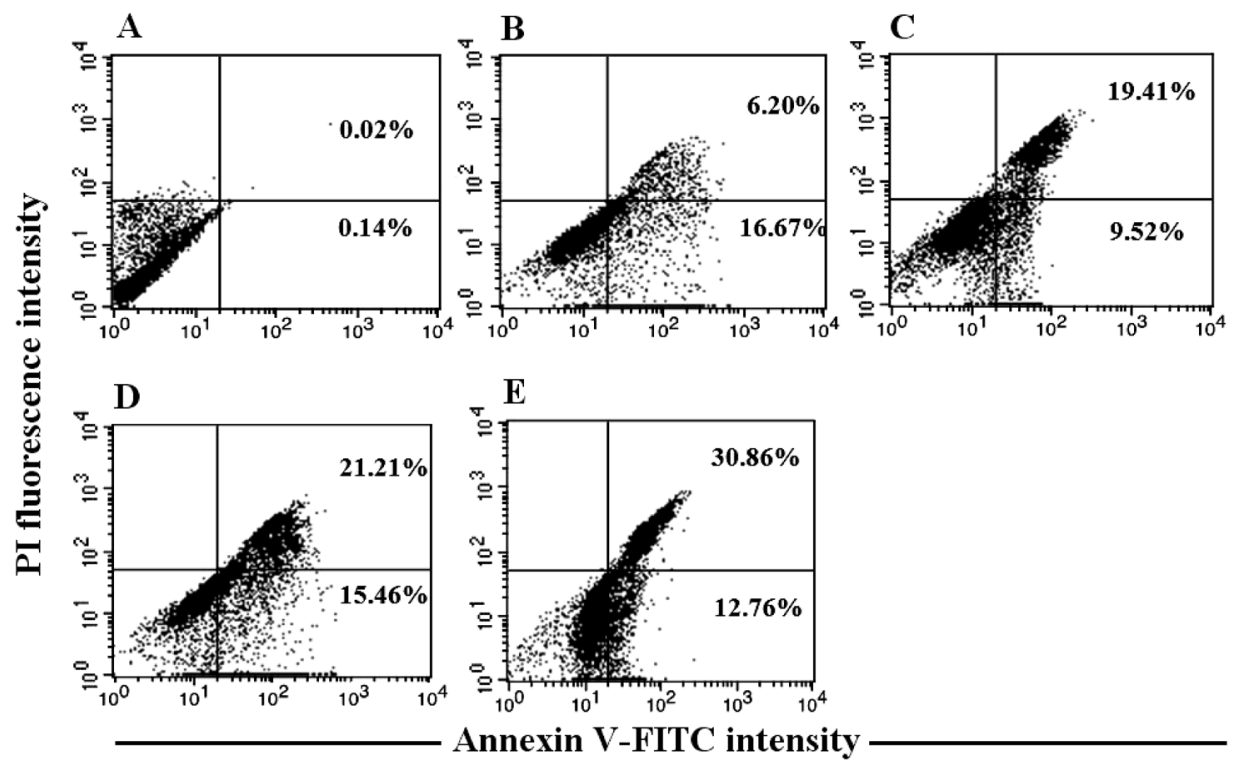

Fig. 5. The Results of the Flow Cytometric Analysis of the Liu-Shen-Wan Supernatant (LSWS)-Induced HepG2 Apoptosis as Determined by Annexin V-FITC/PI Double Staining

Cells $\left(5 \times 10^{5}\right)$ were cultured with or without the LSWS ((B) $0.1 \mu \mathrm{g} / \mathrm{mL}$; (C) $1 \mu \mathrm{g} / \mathrm{mL}$; (D) $10 \mu \mathrm{g} / \mathrm{mL}$; (E) $\left.100 \mu \mathrm{g} / \mathrm{mL}\right)$ for $24 \mathrm{~h}$. Cells were stained with Annexin V-FITC for $15 \mathrm{~min}$ at room temperature and were counterstained with $50 \mathrm{~g} / \mathrm{mL}$ PI. The percentage of cells in each quadrant is indicated in the corners of the dot plot. The lower right and upper right quadrants represent early and late apoptosis, respectively.

future to fully evaluate the toxicity of LSWS.

Effects of the LSWS on the Apoptosis of Tumor Cell Lines Both LSW and the LSWS produced a dose-related growth inhibitory effect on HepG2 cells (Fig. 4). Compared with control, LSW $(1-100 \mu \mathrm{g} / \mathrm{mL})$ and LSWS $(0.1-100 \mu \mathrm{g} / \mathrm{mL})$ treatments induced significant decrease of cell viability $(p<0.001)$. As for LSWR, it increased slightly the cell viability at lower concentrations $(0.1-1 \mu \mathrm{g} / \mathrm{mL})$, but significantly decreased of cell viability at higher concentrations $(p<0.001$ vs. control). The positive control doxorubicin showed cytotoxity both in HepG2 and L02 cells, with the $\mathrm{IC}_{50} 0.27$ and $1.04 \mu \mathrm{g} / \mathrm{mL}$, respectively. The $\mathrm{IC}_{50}$ for $\mathrm{L} 02$ cells is about 4 -flod of that for HepG2. However, LSWS's performance is better than doxorubicin. Its $\mathrm{IC}_{50}$ for L02 cells $(62.58 \mu \mathrm{g} / \mathrm{mL})$ is about 12 -flod of that for HepG2 $(5.54 \mu \mathrm{g} / \mathrm{mL})$. At $10 \mu \mathrm{g} / \mathrm{mL}$ concentration, LSWS inhibited $>40 \%$ HepG 2 , but just $<10 \%$ L02. That 
indicated that LSWS has relative selective cytotoxicy to hepatoma cell line to a certain degree. To test whether the cell death was a result of apoptosis in HepG2 cells, a flow cytometric analysis was performed using Annexin V and PI. Early stage apoptotic cells will only take up the Annexin V stain but will remain PI negative, and late-stage apoptotic cells will be positive for both Annexin V and PI. The results indicated that there were very few PI-positive and Annexin-V-positive cells in the control cultures (Fig. 5A, top first panel), while $23-44 \%$ of the LSWS-treated cells were labeled (lower right and upper right quadrants representing early and late apoptosis, respectively) in a concentration-dependent manner. After exposure of the cells to $0.1 \mu \mathrm{g} / \mathrm{mL}$ of the LSWS for $24 \mathrm{~h}$, a significant number of cells showed Annexin V-FITC positive and PI negative staining (an increase in the number of dots in the bottom right quadrant from $0 \%$ of control cells to $17 \%$ of treated cells) (Fig. 5B). Following an increase of the LSWS to $100 \mu \mathrm{g} / \mathrm{mL}$, the number of cells in advanced apoptosis (stained positive with both Annexin V-FITC and PI; upper right quadrant) was significantly increased from $6 \%$ of control cells to $31 \%$ of the treated cells (Figs. $5 \mathrm{~B}-\mathrm{E}$ ). ${ }^{20}$ )

The Effect of LSWS on the Bradykinin-Induced Substance P Release from Cultured DRG Cells To clarify the possible pharmacological mechanism underlying the effects of the LSWS on the behavior responses to pain, we examined the effects of the LSWS on the release of substance P by cul- tured DRG cells induced by bradykinin treatment. As shown in Fig. 6, when the LSWS $(10 \mu \mathrm{g} / \mathrm{mL})$ was used alone, it had no significant effect on the substance $\mathrm{P}$ release from normal cultured DRG cells. However, the LSWS treatment (1 and $10 \mu \mathrm{g} / \mathrm{mL})$ led to a potent inhibitory effect $(159.3 \pm 13.2,110.6 \pm$ $9.3 \mathrm{pg} / \mathrm{dish}$, respectively) on the bradykinin-evoked rapid re-

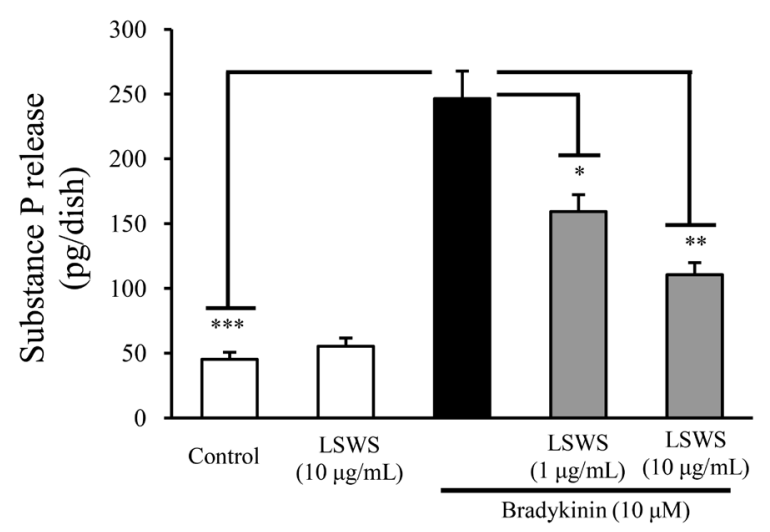

Fig. 6. The Effect of the Liu-Shen-Wan Supernatant (LSWS) on the Substance P Release from Rat Dorsal Root Ganglion (DRG) Cells

Except for the cells in the control group, all of the other cultured cells were exposed to bradykinin $(10 \mu \mathrm{M})$ or to both bradykinin $(10 \mu \mathrm{M})$ and the LSWS $(10 \mu \mathrm{g} / \mathrm{mL})$ for $3 \mathrm{~h}$. The substance P content in the collected culture medium was measured by a radioimmunoassay. The values are the means \pm S.E.M. of six replicates. $* p<0.05$, $* * p<0.01$, and $* * * p<0.001$.
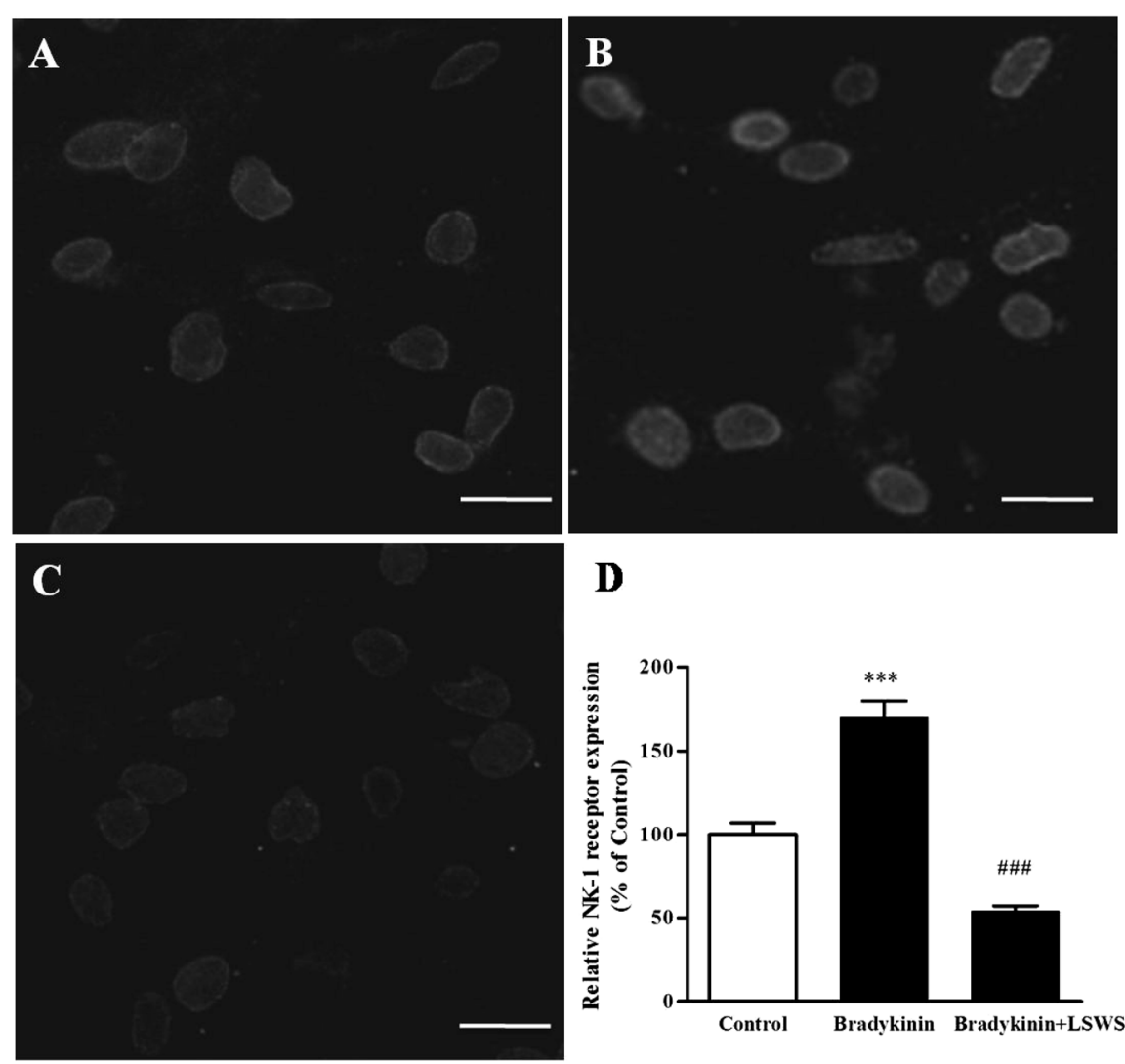

D

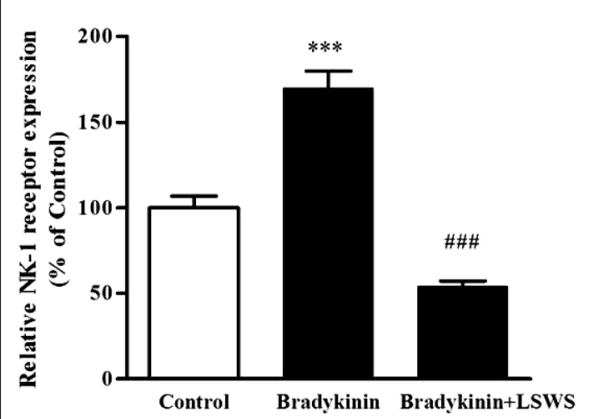

Fig. 7. The Effect of the Liu-Shen-Wan Supernatant (LSWS) on the Neurokinin 1 (NK-1) Receptor Expression in Rat Dorsal Root Ganglion (DRG) Cells

Compared with control cells (A), the NK-1 receptor expression was significantly up-regulated by bradykinin treatment (B). Treatment with the LSWS (10 $\mu$ g/mL) could significantly down-regulate the bradykinin-induced expression of the NK-1 receptor (C). (D) The relative levels were analyzed by determining the optical density of fluorescence signals. The $4 \%$ paraformaldehyde-fixed cultured DRG cells on cover-glasses were incubated with goat serum (1:9 dilution) for $1 \mathrm{~h}$ at room temperature. Then, an anti-NK-1 antibody (1:1000 dilution) was added to the cells, which were incubated at $4{ }^{\circ} \mathrm{C}$ overnight. After being washed with PBS, Alexa Fluor 546 (1:1000 dilution; Sigma) was added, and cells were incubated for another $1 \mathrm{~h}$ at room temperature. Finally, the fluorescence signals were visualized with a microscope. Scale bar, $10 \mu \mathrm{m}$. The values are the means \pm S.E.M. of six replicates. ${ }^{* * *} p<0.001 v s$. control, and ${ }^{\# \#} p<0.001$ vs. bradykinin-treated group. 


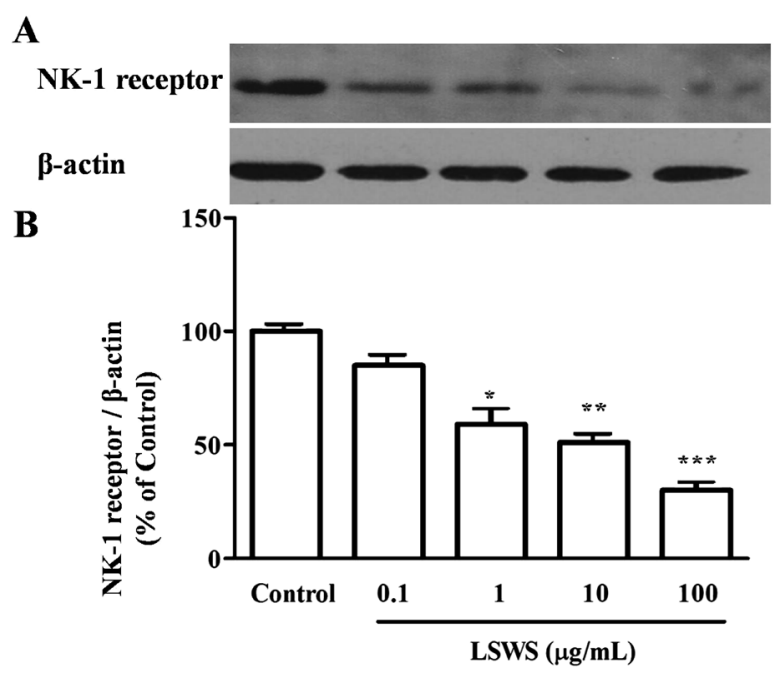

Fig. 8. The Effect of the Liu-Shen-Wan Supernatant (LSWS) on the Neurokinin-1 (NK-1) Receptor Expression in HepG2 Cells

Cells grown in $35 \mathrm{~mm}$ dishes were disrupted. A total of $20 \mu \mathrm{g}$ of protein were separated by electrophoresis on $12 \%$ SDS-polyacrylamide gels, and then the proteins were electrophoretically transferred to PVDF membranes. Antibody binding was detected by using an enhanced chemiluminescence kit with hyper-ECL film. (A) Representative Western blots of the NK-1 receptor and $\beta$-actin expression. (B) The relative levels were analyzed by determining the ratio of the NK-1 receptor/ $\beta$ actin. The LSWS $(0.1-100 \mu \mathrm{g} / \mathrm{mL})$ treatment significantly decreased the expression of the NK-1 receptor in HepG2 cells compared with the control cells. The values are the means \pm S.E.M. of three replicates. $* p<0.05, * * p<0.01$, and $* * * p<0.001$ vs. control.

lease of substance P $(246.5 \pm 21.2 \mathrm{pg} / \mathrm{dish})$.

Immunocytochemical Localization of the NK-1 Receptor As shown in Fig. 7, the NK-1 receptors were distributed on the membrane and in the cytoplasm of DRG cells. As expected, the expression of the NK-1 receptor was significantly up-regulated by bradykinin treatment. In contrast, the addition of the LSWS $(10 \mu \mathrm{g} / \mathrm{mL})$ led to a significant downregulation of the bradykinin-induced expression of the NK-1 receptor.

Effect of LSWS on the NK-1 Receptor Expression in HepG2 Cells The substance P/NK-1 receptor system is a common target for both analgesic and anticancer drugs. Based on the above results showing the LSWS-induced changes in neurons (Figs. 6, 7), we hypothesized that the LSWS might also affect the NK-1 receptor expression in tumor cells. As shown in Fig. 8, the LSWS $(0.1-100 \mu \mathrm{g} / \mathrm{mL})$ treatment significantly down-regulated the expression of the NK-1 receptor in HepG2 cells compared with control cells.

The LSWS-Induced Apoptotic Pathway in HepG2 Cells Apoptosis manifests in two major execution programs downstream of the death signal: the caspase pathway and mitochondrial dysfunction. ${ }^{21,22)}$ Caspases play a central role in the transduction of various drug-induced apoptotic signals in HepG2 cells. $^{23-25)} \mathrm{Bcl}-2$ family members have been described as key regulators of mitochondrial permeability, ${ }^{22)}$ and also play critical roles in HepG2 apoptosis. ${ }^{26)}$ Therefore, we examined the effects of the LSWS on the expression levels of caspases and Bcl-2 family members in the HepG2 cells. There was a slight increase in the caspases 3, 8 and 9 levels, as well as a decrease in the Bal-2/Bax ratio in the $0.1 \mathrm{mg} / \mathrm{mL}$ treated group compared to the control. This was in contrast to the $1-100 \mathrm{mg} / \mathrm{mL}$-treated group, in which an decrease in the caspase 3, 8 and 9 levels, and an increase in the Bal-2/ Bax ratio, were detected compared to the control (Figs. 9, 10). In addition to the NK-1 receptor-dependent growth inhibition,
A

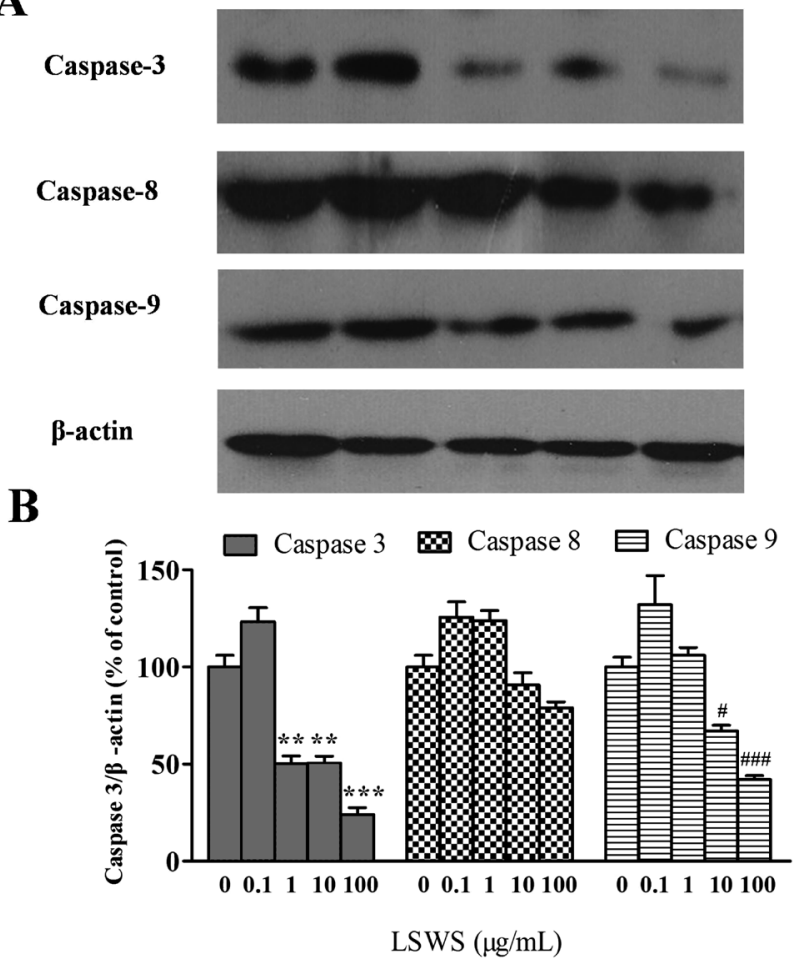

Fig. 9. The Inhibition of Caspases 3, 8, and 9 by the Liu-Shen-Wan Supernatant (LSWS) in HepG2 Cells

Cells grown in $35 \mathrm{~mm}$ dishes were disrupted, and $20 \mu \mathrm{g}$ of protein were separated by electrophoresis on $12 \%$ SDS-polyacrylamide gels, and then the proteins were electrophoretically transferred to PVDF membranes. Antibody binding was detected by using the enhanced chemiluminescence kit with hyper-ECL film. The exposure of HepG2 cells to the LSWS $(1-100 \mu \mathrm{g} / \mathrm{mL})$ resulted in a concentrationdependent inhibition of caspase 3 , caspase 8 and caspase 9. (A) Representative western blots of caspase 3 , caspase 8 , caspase 9 and $\beta$-actin expressions. (B) The relative levels were analyzed by determining the ratio of caspase $/ \beta$-actin. The values are the means \pm S.E.M. of three replicates. $* * p<0.01$, and $* * * p<0.001 v s$. caspase 3 expression in control. ${ }^{\#} p<0.05$ and ${ }^{\# \#} p<0.001 v$ s. caspase 9 expression in control.

LSWS induced mitochondria-mediated apoptosis at a higher concentration.

\section{DISCUSSION}

Traditional LSW has been used clinically for more than 250 years, and increasing attention is being paid to its scientific evaluation. A previous study demonstrated that realgarcontaining LSW $(200 \mathrm{mg} / \mathrm{kg})$ was much less acutely toxic than sodium arsenite and arsenate in mouse livers. ${ }^{5)}$ Unfortunately, when the dose of such a drug was increased to $964 \mathrm{mg} / \mathrm{kg}$ (nearly five-fold the $200 \mathrm{mg} / \mathrm{kg}$ dose), it induced severe liver injury in mice. The slag following LSW alcohol solution (LSWR) also destroyed animal livers in experimental studies. However, the supernatant of LSW ethanol extraction (LSWS) seemed to be safer in the present study. Using the supernatant might have reduced the arsenic content of test drug. This could be part of the reason for the decreased liver damage seen with the supernatant fraction. However, the possibility still exists that arsenic bioaccumulation may lead to the development of toxic effects over time, even when the amount present is not sufficient to produce an acute effect in a single dose study. Therefore, a study on the long-term toxicity will be necessary to confirm the safety of LSWS in the future.

These results indicate that the LSWR may include the ma- 
$\mathbf{A}$

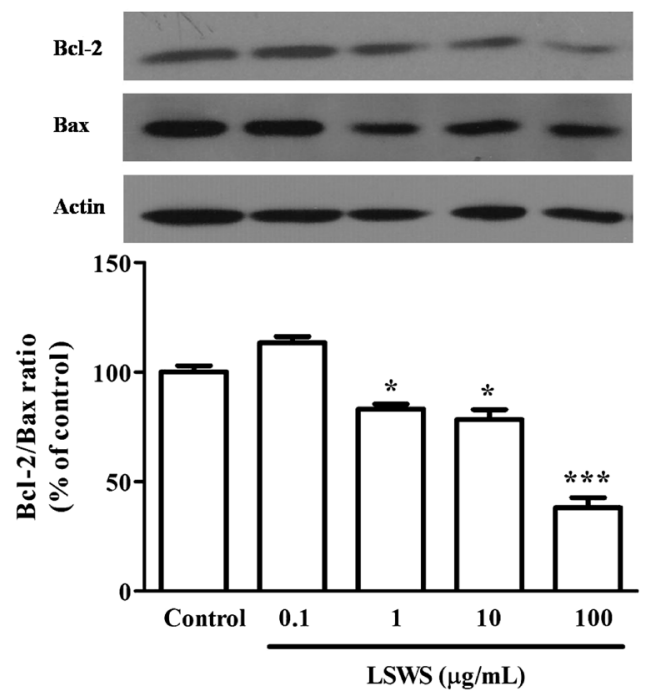

Fig. 10. The Effect of the Liu-Shen-Wan Supernatant (LSWS) on the Bcl-2/Bax Expression Ratio in HepG2 Cells

Cells grown in $35 \mathrm{~mm}$ dishes were disrupted, and $20 \mu \mathrm{g}$ of protein were separated by electrophoresis on $12 \%$ SDS-polyacrylamide gels, and then the proteins were electrophoretically transferred to PVDF membranes. Antibody binding was detected by using the enhanced chemiluminescence kit with hyper-ECL film. (A) Representative Western blots of the Bcl-2 and Bax expression. (B) The relative levels were analyzed by determining the ratio of $\mathrm{Bcl}-2 / \mathrm{Bax}$. The LSWS $(1-100 \mu \mathrm{g} / \mathrm{mL})$ significantly down-regulated the $\mathrm{Bcl}-2 / \mathrm{Bax}$ expression ratio in HepG2 cells compared with the control. The values are the means \pm S.E.M. of three replicates. $* p<0.05, * * p<0.01$ and $* * * p<0.001 v s$. control.

jority of the constituents responsible for the hepatotoxicity of LSW. Even more interesting was the observation that the LSWS retained the analgesic and anticancer activities of LSW.

Ma et al. previously reported that LSW and its individual fractions have analgesic activity. ${ }^{2)}$ However, the underlying mechanism is still unclear. DRGs play an important role in the initiation, transmission, and maintenance of neuropathic pain, as this involves neuropeptides, ion channels, and Gq-proteincoupled receptors, ${ }^{16,18,27)}$ and therefore, a cell culture model using DRG neurons was chosen in the present study. Our previous study indicated that bradykinin could evoke substance $\mathrm{P}$ release, as well as the expression of the NK-1 receptor in this model. ${ }^{8}{ }^{818)}$ The present study has demonstrated that the LSWS inhibited bradykinin-induced substance $\mathrm{P}$ release and NK-1 receptor expression. These finding indicate that the substance P/NK-1 receptor system might be involved in LSWS's analgesic activity.

We further explored the links between the substance $\mathrm{P} /$ NK-1 receptor system and the LSWS's anticancer activity, since the substance P/NK-1 receptor system also has a critical role in tumor development ${ }^{7)}$ and since the LSWS could affect the substance P/NK-1 receptor levels. It has previously been reported that NK-1 receptor blockers could inhibit the growth of cancer cells, such as human epidermoid cancer cells, pancreatic cancer cells, gastrointestinal cancer cells, and lung cancer cells..$^{9-12)}$ In the present study, the LSWS suppressed the growth of HepG2 cells, and down-regulated the expression of the NK-1 receptor, which indicated that an NK-1 receptordependent pathway might be involved in the LSWS-induced cancer cell growth inhibition. These findings described here for the first time the antitumor action of LSWS could be due to NK-1 receptor antagonist pharmacological profile. Moreover, these findings are in agreement with previously described in other different carcinoma cell lines. ${ }^{9-12}$ )
Apart from the above-mentioned substance P/NK-1 receptor system, caspases and the Bcl-2 family were thought to play a critical role in the growth inhibition in tumor cells, such as human promyelocytic leukemia HL-60 cells ${ }^{3,28)}$ and human breast adenocarcinoma MCF-7 cells. ${ }^{29)}$ In addition, cinobufacini, an extract from Calculus bovis, induced apoptosis in HepG2 cells through mitochondria- and caspasedependent pathways..$^{16,30-34)}$ We found that the LSWS induced mitochondria-mediated apoptosis at a higher concentration $(1-100 \mu \mathrm{g} / \mathrm{mL})$. Therefore, the NK-1 receptor, as well as Bcl-2/ Bax, apparently takes part in the LSWS-induced growth inhibition in HepG2 cells.

In conclusion, we have isolated a safer LSW fraction which maintained the analgesic and anticancer activity of LSW, but with reduced hepatotoxicity. We also found that the substance $\mathrm{P} / \mathrm{NK}-1$ receptor system was involved in both the analgesic and anticancer activities of this fraction. The present findings will be useful to develop more effective and less toxic preparations of LSW that will be acceptable to the international community.

Acknowledgments This work was supported by National Natural Science Foundation of China (81373842 and 81101538), Natural Science Foundation of China Hubei (2012FFC13501) and Grants from South-Central University for Nationalities (CZQ11037 and XTZ10001).

\section{REFERENCES}

1) Kimura M, Osada E, Matsui T, Kobayashi C. Fundamental research for the pharmacological activity of Oriental drugs. IX. On the combined action of several crude drugs consisting in "Rokusingan" for the anti-inflammatory effect. Yakugaku Zasshi, 88, 135-139 (1968).

2) Ma HY, Kou JP, Wang JR, Yu BY. Evaluation of the antiinflammatory and analgesic activities of Liu-Shen-Wan and its individual fractions. J. Ethnopharmacol., 112, 108-114 (2007).

3) Dai XM, Xu F, Guo Y. Experimental study of Liu-shen-wan on inducing leukemia cell apoptosis and correlative gene of control apoptosis. Liaoning Journal of Traditional Chin. Med., 30, 431-433 (2003).

4) Bensky D, Barolet R. Chinese Herbal Medicine: Formulas and Strategies. 2nd ed, Eastland Press, Seattle, p. 87 (1993).

5) Liu J, Liang SX, Lu YF, Miao JW, Wu Q, Shi JS. Realgar and realgar-containing Liu-Shen-Wan are less acutely toxic than arsenite and arsenate. J. Ethnopharmacol., 134, 26-31 (2011).

6) Ancient Way Acupuncture Blog. "Six Spirit Pills/Liu Shen Wan: Is it the Arsenic or Psychedelic Toad Venom that causes skin blistering and peeling?": 〈http://ancientway.com/blog/?p=1071/ March 2012), cited on 7 March, 2012.

7) Muñoz M, Covenas R. Neurokinin-1 receptor: a new promising target in the treatment of cancer. Discov. Med., 10, 305-313 (2010).

8) Tang HB, Inoue A, Iwasa M, Hide I, Nakata Y. Substance P release evoked by capsaicin or potassium from rat cultured dorsal root ganglion neurons is conversely modulated with bradykinin. $\mathrm{J}$. $\mathrm{Neu}$ rochem., 97, 1412-1418 (2006).

9) Muñoz M, Rosso M, Aguilar FJ, Gonzalez-Moles MA, Redondo M, Esteban F. NK-1 receptor antagonists induce apoptosis and counteract substance P-related mitogenesis in human laryngeal cancer cell line HEp-2. Invest. New Drugs, 26, 111-118 (2008).

10) Muñoz M. Rosso M. Coveas R. The NK-1 receptor is involved in the antitumoural action of L-733,060 and in the mitogenic action of substance P on human pancreatic cancer cell lines. Lett. Drug Des. Discov., 3, 323-329 (2006).

11) Rosso M, Robles-Frías MJ, Coveñas R, Salinas-Martín MV, Muñoz 
M. The NK-1 receptor is expressed in human primary gastric and colon adenocarcinomas and is involved in the antitumor action of L-733,060 and the mitogenic action of substance $\mathrm{P}$ on human gastrointestinal cancer cell lines. Tumour Biol., 29, 245-254 (2008).

12) Muñoz M, González-Ortega A, Rosso M, Robles-Frias MJ, Carranza A, Salinas-Martín MV, Coveñas R. The substance P/neurokinin-1 receptor system in lung cancer: focus on the antitumor action of neurokinin-1 receptor antagonists. Peptides, 38, 318-325 (2012).

13) Cao Y, Liang QL, Zhang HY, Wang YM, Bi KS, Luo GA. Screening and identification of multi-classified components in Liu Shen Wan using multi-dimension high performance liquid chromatography tandem mass spectrometry system. Chinese Journal of Analytical Chemistry, 36, 39-45 (2008).

14) Reagan-Shaw S, Nihal M, Ahmad N. Dose translation from animal to human studies revisited. FASEB J., 22, 659-661 (2007).

15) Yoshiyama S, Horinouchi T, Miwa S, Wang HH, Kohama K, Nakamura A. Effect of cigarette smoke components on vascular smooth muscle cell migration toward platelet-derived growth factor BB. J. Pharmacol. Sci., 115, 532-535 (2011).

16) Li YS, Wang JX, Jia MM, Liu M, Li XJ, Tang HB. Dragon's blood inhibits chronic inflammatory and neuropathic pain responses by blocking the synthesis and release of substance $\mathrm{P}$ in rats. J. Pharmacol. Sci., 118, 43-54 (2012).

17) Gerard NP, Garraway LA, Eddy RL Jr, Shows TB, Iijima H, Paquet JL, Gerard C. Human substance P receptor (NK-1): organization of the gene, chromosome localization, and functional expression of cDNA clones. Biochemistry, 30, 10640-10646 (1991).

18) Tang HB, Li YS, Arihiro K, Nakata Y. Activation of the neurokinin1 receptor by substance $\mathrm{P}$ triggers the release of substance $\mathrm{P}$ from cultured adult rat dorsal root ganglion neurons. Mol. Pain, 3, 42 (2007).

19) Lowry OH, Rosebrough NJ, Farr AL, Randall RJ. Protein measurement with the Folin phenol reagent. J. Biol. Chem., 193, 265-275 (1951).

20) Niu M, Sun Y, Liu X, Tang L, Qiu R. Tautomycetin induces apoptosis by inactivating Akt through a PP1-independent signaling pathway in human breast cancer cells. J. Pharmacol. Sci., 121, 17-24 (2013)

21) Gross A, McDonnell JM, Korsmeyer SJ. BCL-2 family members and the mitochondria in apoptosis. Genes Dev., 13, 1899-1911 (1999).

22) Martinou JC, Youle RJ. Mitochondria in apoptosis: Bcl-2 family members and mitochondrial dynamics. Dev. Cell, 21, 92-101 (2011).

23) Castaneda F, Rosin-Steiner S. Low concentration of ethanol induce apoptosis in HepG2 cells: role of various signal transduction path- ways. Int. J. Med. Sci., 3, 160-167 (2006).

24) Granado-Serrano AB, Martin MA, Bravo L, Goya L, Ramos S. Quercetin induces apoptosis via caspase activation, regulation of Bcl-2, and inhibition of PI-3-kinase/Akt and ERK pathways in a human hepatoma cell line (HepG2). J. Nutr., 136, 2715-2721 (2006).

25) Huang SP, Chen JC, Wu CC, Chen CT, Tang NY, Ho YT, Lo C, Lin JP, Chung JG, Lin JG. Capsaicin-induced apoptosis in human hepatoma HepG2 cells. Anticancer Res., 29, 165-174 (2009).

26) Ji YB, Gao SY, Ji CF, Zou X. Induction of apoptosis in HepG2 cells by solanine and Bcl-2 protein. J. Ethnopharmacol., 115, 194-202 (2008).

27) Chen Y, Li GW, Wang C, Gu Y, Huang LY. Mechanisms underlying enhanced $\mathrm{P} 2 \mathrm{X}$ receptor-mediated responses in the neuropathic pain state. Pain, 119, 38-48 (2005).

28) Ma J. Influence of Liushenwan on Inducing Apoptosis in Leukemia Cells and Apoptosis-Related Genes, Tianjin College of Traditional Chinese Medicine thesis, 2003.

29) Li W, Meng Y, Zhao L, Ding S, Sun L. Experiment research of the reversed effect of Liushenwan on the inhibiton effect of Erigeron breviscapus injection on tumor cell apotosis. Hebei J. TCM, 28, 940-942 (2006).

30) Qi F, Li A, Inagaki Y, Xu H, Wang D, Cui X, Zhang L, Kokudo $\mathrm{N}$, Du G, Tang W. Induction of apoptosis by cinobufacini preparation through mitochondria- and Fas-mediated caspase-dependent pathways in human hepatocellular carcinoma cells. Food Chem. Toxicol., 50, 295-302 (2012).

31) Qi F, Li A, Zhao L, Xu H, Inagaki Y, Wang D, Cui X, Gao B, Kokudo N, Nakata M, Tang W. Cinobufacini, an aqueous extract from Bufo bufo gargarizans Cantor, induces apoptosis through a mitochondria-mediated pathway in human hepatocellular carcinoma cells. J. Ethnopharmacol., 128, 654-661 (2010).

32) Qi FH, Li AY, Lv H, Zhao L, Li JJ, Gao B, Tang W. Apoptosisinducing effect of cinobufacini, Bufo bufo gargarizans Cantor skin extract, on human hepatoma cell line BEL-7402. Drug Discov. Ther., 2, 339-343 (2008).

33) Qi F, Inagaki Y, Gao B, Cui X, Xu H, Kokudo N, Li A, Tang W. Bufalin and cinobufagin induce apoptosis of human hepatocellular carcinoma cells via Fas- and mitochondria-mediated pathways. Cancer Sci., 102, 951-958 (2011).

34) Qi F, Li A, Inagaki Y, Kokudo N, Tamura S, Nakata M, Tang W. Antitumor activity of extracts and compounds from the skin of the toad Bufo bufo gargarizans Cantor. Int. Immunopharmacol., 11, 342-349 (2011). 